Research Article

\title{
IIIB-IV Degree Perineal Rupture Repair Using Overlapping and End-to-End Techniques with Pudendal Block Anesthesia
}

\section{Hasil Reparasi Robekan Perineum Derajat IIIB-IV Teknik Tumpang Tindib dan Ujung ke Ujung dengan Anestesi Blok Pudendal}

\author{
Nuring Pangastuti ${ }^{1}$, Junizaf ${ }^{2}$, Ibnu Pranoto', Budi I Santoso², Tyas Priyatini ${ }^{2}$ \\ Department of Obstetrics and Gynecology \\ ${ }^{1}$ Faculty of Medicine University of Gadjab Mada \\ Dr. Sardjito Central General Hospital \\ Yogyakarta \\ ${ }^{2}$ Faculty of Medicine University of Indonesia \\ Dr. Cipto Mangunkusumo General Hospital \\ Jakarta
}

\begin{abstract}
Objective: To compare the incidence of persistent sonographic anal sphincter defect, fecal urgency, anal and fecal incontinence after IIIbIV degree perineal rupture repair using overlapping and end-to-end technique.

Method: An open clinical trial with randomization was carried out in July 2010-April 2012. The population consisted of the patients who underwent vaginal delivery in Dr. Sardjito Central General Hospital, Sleman District General Hospital, as well as Tegalrejo, Jetis and Mergangsan Community Health Centers who did no have complaints of fecal urgency, anal incontinence, and/or fecal incontinence, and suffered IIIb-IV degree perineal rupture repaired within less than 24 hours of rupture. The exclusion criteria included conditions in which patients could not undergo repair at the moment (shock, uncooperative patient). Fourty-eight research samples were divided into 2 groups, 24 samples for each of the treatment group (overlapping repair) and the control group (end-to-end repair). Local anesthesia was performed in a pudendal-block manner.

Result: Success of the repair was assessed based on the presence of persistent sonographic anal sphincter defects in the 6-week evaluation after repair. Successful repair was higher in the overlapping group than that of the end-to-end group $(94.74 \%$ vs $81.25 \%, \mathrm{p}=0.31)$. Clinically and based on the Fecal Continence Scoring Scale (FCSS), evaluation at weeks II and VI indicated successful repair in both groups.

Conclusion: There was no difference in the incidence of persistent sonographic anal sphincter defects, fecal urgency, anal incontinence, and fecal incontinence, after IIIb-IV degree perineal rupture repair using overlapping technique in comparison with end-to-end technique.

[Indones J Obstet Gynecol 2015; 3: 154-160]
\end{abstract}

Keywords: end-to-end technique, III-IV degree perineal rupture, obstetric perineal rupture, overlapping technique

\begin{abstract}
Abstrak
Tujuan: Untuk membandingkan kejadian persistent sonographic anal sphincter defect, urgensi fekal, inkontinensia anal maupun fekal, pascareparasi robekan perineum derajat IIIb-IV dengan teknik tumpang tindib dan ujung ke ujung.

Metode: Dilakukan penelitian uji klinis terbuka dengan randomisasi pada bulan Juli 2010-April 2012. Kriteria inklusi adalah pasien persalinan pervaginam di RSUP Dr. Sardjito, RSUD Kabupaten Sleman, Puskesmas Tegalrejo, Jetis dan Mergangsan, Yogyakarta, yang sebelumnya tidak memiliki keluban urgensi fekal, inkontinensia anal, dan/atau inkontinensia fekal, yang mengalami robekan perineum derajat IIIb-IV dengan reparasi kurang dari 24 jam sejak kejadian ruptur. Kriteria eksklusi adalab pasien yang tidak memungkinkan untuk dilakukan reparasi saat itu (syok, tidak dapat bekerja sama). Empat pulub delapan sampel penelitian dibagi dalam dua kelompok, masing-masing 24 sampel pada kelompok perlakuan (reparasi tumpang tindib) dan kelompok kontrol (reparasi ujung ke ujung). Anestesi lokal dilakukan secara blok pudendal.
\end{abstract}

Hasil: Keberhasilan reparasi dinilai dari gambaran persistent sonographic anal sphincter defect 6 minggu pascareparasi. Keberhasilan pada kelompok tumpang tindih lebih tinggi dibandingkan kelompok ujung ke ujung (94,74\% vs 81,25\%, p=0,31). Secara klinis maupun berdasarkan FCSS (Fecal Continence Scoring Scale), evaluasi minggu kedua dan keenam menunjukkan keberhasilan reparasi di kedua kelompok.

Kesimpulan: Tidak terdapat perbedaan kejadian persistent sonograpbic anal sphincter defect, urgensi fekal, inkontinensia anal maupun fekal pascareparasi robekan perineum derajat IIIb-IV dengan teknik tumpang tindih dan teknik ujung ke ujung.

[Maj Obstet Ginekol Indones 2015; 3: 154-160]

Kata kunci: robekan perineum obstetri, robekan perineum derajat III$I V$, teknik tumpang tindih, teknik ujung ke ujung

\section{INTRODUCTION}

Vaginal deliveries remain regarded as the most secure and economical delivery procedures. ${ }^{1}$ In well- conducted aid measures for vaginal delivery, more than $85 \%$ of women experience perineal trauma, and about $60-70 \%$ of them require repair. Some patients 
even experience III-to-IV degree perineal rupture. Research in Europe shows that as many as $0.5-3 \%$ of III-IV degree perineal rupture can be encountered, while in the United States the incidence reach $6-9 \%$, with some sources reporting it to be $20 \% .^{2-5}$ The incidence varies due to differences in the system used to measure the rupture degree, ignorance of both delivery helpers and delivery patients, as well as the assumption that perineal trauma and its accompanying problems are something normal as a consequence of vaginal deliveries. ${ }^{6}$

The standard technique for III-IV degree perineal rupture repair is external anal sphincter suturing using an end-to-end technique. In 1999, Sultan et al introduced a new technique, namely an overlapping technique, and reported a decrease in the incidence of anal incontinence from $41 \%$ to around $8 \%$ in patients undergoing an overlapping repair technique. Research by Fernando et al noted the incidence of fecal urgency to be $32 \%$ in end-to-end cases and $3.7 \%$ in overlapping cases $(\mathrm{p}=0,02){ }^{7}$

Perineum is the outer door of the pelvis that is divided into 2 triangles. The front triangle is called the urogenital triangle, and the triangle located behind the end of the anal canal is the anal triangle. The anal sphincter complex spans 3-4 cm in length and consists of external and internal anal sphincters. 'Loop concepts' (upper, middle, and basal loops) feature a single sphincter unit, which have different structures and functions. ${ }^{8-11}$ The perineal body is a three-dimensional central point between the urogenital triangle and the anal triangle, consisting of the bulbospongiosus muscle fibers, superficial transverse perineal muscle fibers and external anal sphincter muscles. ${ }^{8,11-13}$

Several risk factors for perineal rupture include prolonged second stage, precipitated parturition, a history of perineal rupture, large babies, malposition, instrument-assisted delivery, short perineum, and episiotomy, as well as infiltration of local anesthetics. ${ }^{1,3,12,14-17}$ There are two types perineal rupture due to obstetric anal sphincter injuries, overt and occult. The latter type usually occurs as a result of the error determining the diagnosis, when the III-IV degree perineal rupture is considered to be II degree. ${ }^{18}$

According to Sultan, there are classifications for perineal trauma, namely grade I, which comprise only the vaginal epithelium or perineal skin lacerations; grade II, when only involving the perineal muscles; grade III, which is rupture that reaches the anal sphincter, which is further divided into IIIa ( $<50 \%$ of the external anal sphincter), IIIb $(>50 \%$ of the thickness of the external anal sphincter), and IIIc (when the rupture reaches the internal anal sphincter); and grade IV, which is the III-degree rupture accompanied with anal mucosa. 3,7,16,19,20

Obstetricians have recognized the end-to-end technique since a long time ago as traditional/standard techniques. The overlapping technique is more widely used by colorectal surgeons and in gynecology in cases of fecal incontinence. In general, the results of the repair depend highly on the diagnostic accuracy, the selected repair technique, the thread used, as well as post-repair treatment. Local anesthesia (infiltration or pudendal block) can be used on almost all measures of perineal repair, although general or regional anesthesia produces better sphincter relaxation. 3,7,9,21-23 Evaluation on results of repair is performed at weeks 1, 2, 6, and 3 months after repair. Complaints to be evaluated are complaints related to suturing, possibility of infection up to dehiscence, impaired urination, defecation and dyspareunia. ${ }^{5}$ Evaluation in the third month can be done using ultrasonography, anal manometry, electromyography, measurement of pudendal nerve terminal latency time, and magnetic resonance imaging (MRI). ${ }^{21,24-27}$

Pudendal nerves are somatic nerves found in the pelvic region that innervate the external genitalia in both men and women. These nerves originate from the sacral plexus, from the S2 to S4 ventral rami. The pudendal block anesthesia provides local anesthesia to the perineal region and to approximately the lower third of the vagina. Complications include allergic reactions, systemic toxic reactions, vaginal wall lacerations, hematoma, infections and subgluteal abscess, until fatal complications (convulsions to death). ${ }^{11,23,28-30}$ The anesthetic drug of lignocaine $1-2 \%$ either with or without adrenaline is diluted into $0.5 \%$. The maximum dose is $4 \mathrm{mg} / \mathrm{kg}$ body weight for lignocaine without adrenaline, and 7 $\mathrm{mg} / \mathrm{kg}$ weight for lignocaine with adrenaline (1:200.000). ${ }^{31}$ The pudendal-block anesthetic technique is a relatively inexpensive anesthetic technique, is quite easy to perform and can be done in all delivery-assisting places.

In this study, we aim to compare the incidence of persistent sonographic anal sphincter defect, fecal urgency, anal and fecal incontinence after IIIb-IV degree perineal rupture repair using overlapping and end-to-end technique. 


\section{METHODS}

This study was an open clinical trial with computer randomization. Patients were divided into two groups, the treatment group receiving overlapping perineal rupture repair, and the control group receiving end-to-end repair.

The population consisted of patients who underwent vaginal delivery with perineal rupture degrees IIIb, IIIc or IV, hospitalized in Dr. Sardjito Central General Hospital, Sleman District General Hospitals, as well as Tegalrejo, Jetis and Mergangsan Community Health Centers in Yogyakarta. The inclusion criteria included patients without previous complaints of fecal urgency, fecal or anal incontinence, with the repair being performed within less than 24 hours of the rupture, and the patients were willing to participate in the study. The exclusion criteria included conditions where the patients could not undergo repair at the moment (shock or uncooperative patient). The study was conducted from July 2010 until April 2012.

The independent variable consisted of perineal rupture degrees IIIb, IIIc or IV repair using overlapping and end-to-end techniques. The dependent variable was repair success defined as the absence of persistent sonographic anal sphincter defects, fecal urgency, anal incontinence, and fecal incontinence.

Repair was initiated with pudendal-block anesthesia using lidocaine $1 \% .^{23,30}$ The rectal mucosa was sutured using interrupted sutures with polyglactin 910 thread number 3-0, intraluminal knots, followed by continued suturing of internal anal sphincter. Repair of the external anal sphincter was performed using techniques determined based on computer randomization, including the overlapping technique and end-to-end technique, with polyglactin 910 thread number 2-0. The end-to-end repair technique is a suturing technique performed by bringing the ends of the external anal sphincter on both sides to be united and to perform sutures at the ends of the muscles with sufficient thickness (3-4 sutures). The overlapping repair technique is a suturing technique that brings together the ends of the external anal sphincter with mattress sutures resulting in a greater surface of inter-contacting tissues between the two ends of the muscles. ${ }^{9}$ Perineal muscles were sutured interruptedly using the same thread. Repair of the vaginal mucosa began at $1 \mathrm{~cm}$ above the top of the rupture wounds, with unlocked running sutures, and then the perineal skin was sutured using continuous subcuticular suturing, using polyglactin 910 number 3-0.
Persistent sonographic anal sphincter defects refer to fixed pictures of ultrasonography in the forms of anal sphincter muscle defects after perineal rupture repair, either with or without clinical complaints. ${ }^{25,26}$ Fecal urgency refers to the condition where patients feel like they would like to have a bowel movement and cannot hold it until they arrive at the toilet (less than 5 minutes). ${ }^{3,32}$ In this study, anal incontinence is used in cases of flatus incontinence in order to distinguish it from fecal incontinence, which is defined as the inability to control the discharge of liquid and solid feces. ${ }^{16,17,32}$

Antibiotics were given prior to the repair action, that was 1 gram of Ampicillin intravenously, with allergy testing performed beforehand. Patients with allergies can take 1 gram of Cefotaxime. Oral antibiotic Ampicillin caplets $500 \mathrm{mg} / 6$ hours and Metronidazole tablets $500 \mathrm{mg} / 8$ hours were given for 5 days. Analgesics were given orally, specifically mefenamic acid caplets $500 \mathrm{mg}$ every 8 hours, or ibuprofen tablets $100 \mathrm{mg}$ every 12 hours for 5 days. A spoon of laxantia syrup was given every 12 hours for 7 days along with a high-fiber diet. Suppository drug administration was not allowed.

The Dauer catheter number 14F was installed for 24 hours. Residual urine examination was performed no later than 6 hours after the catheter had been removed and the patient could urinate spontaneously. Perineal treatment was done by always maintaining cleanliness. The patient could be discharged from the hospital after they could urinate spontaneously without any complaint.

Evaluation at weeks 1 and 2 after the repair was made to assess any complaints, the condition of the repaired tissue, the ability of flatus and bowel movement. Assessment was also carried out to fill the Fecal Continence Scoring Scale. ${ }^{3}$ At week 6, evaluation was performed using digital rectal examination and ultrasonography. Pelvic floor muscle exercises in a Kegel manner was introduced to patients at week 1 after repair.

Ultrasonography examination using a Voluson 730 pro 3D USG tool in a transperineal manner was performed to assess the presence of persistent sonographic anal sphincter defects. Abdominal probe that had been lubricated and covered with a special type of plastic was placed on the fourchette. Assessment was made to determine the presence or absence of defects in the internal and external anal sphincter. 
Repair was considered successful if there were no persistent sonographic anal sphincter defect pictures obtained in the evaluation at week 6 after repair. Repair was considered as failed if there were pictures of persistent sonographic anal sphincter defects, and/or fecal urgency complaints, and/or anal incontinence, and/or fecal incontinence obtained at week 6 after repair, when dehiscence until the external anal sphincter occurred, or when failure or complications of anesthesia occurred.

\section{RESULTS}

Forty-eight research samples with IIIb-IV degree perineal rupture were recruited, 24 patients random- ized to the repair group using an overlapping technique and 24 patients randomized to the repair group using an end-to-end technique.

During the week 1 and 2 evaluation, all the patients were considered to have successful repair of the perineal rupture. After 6 week evaluation, there were 5 patients who cannot be contacted in the overlapping group, while in the end-to-end group there were 8 patients who cannot be contacted for follow-up. Therefore, we have 19 samples in the overlapping group and 16 samples in the end-to-end group at 6 weeks post-repair. There was one sample who had failed repair in the overlapping group, while three patients in the end-to-end group had failed repair.

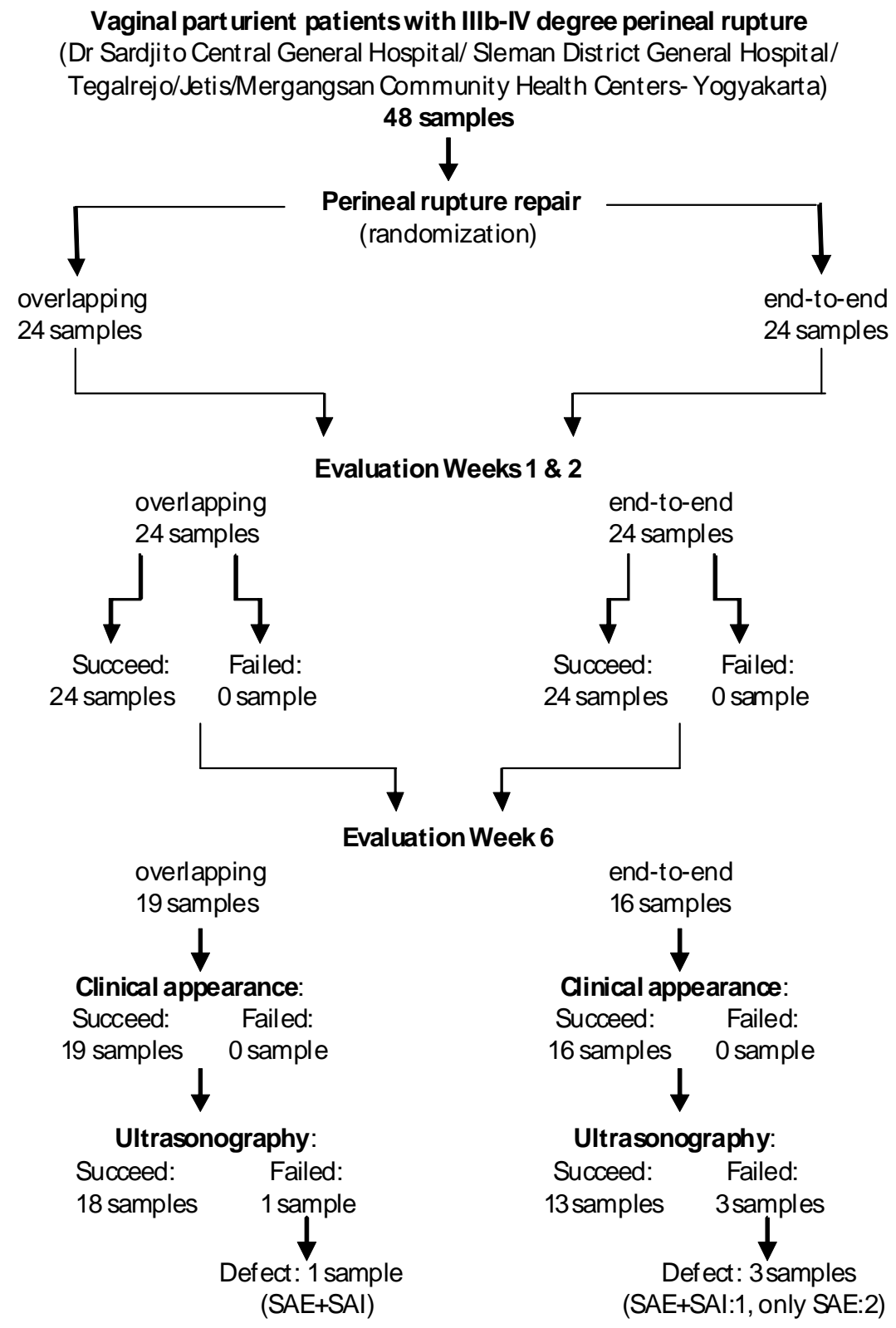


Table 1. The Occurrence of Persistent Sonographic Anal Sphincter Defects at Evaluation Week 6

\begin{tabular}{|c|c|c|c|c|c|}
\hline \multirow{2}{*}{ Repair Technique } & \multicolumn{2}{|c|}{ Internal anal sphincter defects } & \multirow{2}{*}{$\%$} & \multirow{2}{*}{$\mathrm{RR}(95 \% \mathrm{CI})$} & \multirow{2}{*}{$\mathrm{p}$} \\
\hline & Yes & No & & & \\
\hline Overlapping & 1 & 18 & 5.26 & $0.83(0.05-14.48)$ & 1.00 \\
\hline End-to-End & 1 & 15 & 6.25 & & \\
\hline \multirow{2}{*}{ Repair Technique } & \multicolumn{2}{|c|}{ External anal sphincter defects } & $\%$ & $\mathrm{RR}(95 \% \mathrm{CI})$ & $\mathrm{n}$ \\
\hline & Yes & No & & & $\mathbf{r}$ \\
\hline Overlapping & 1 & 18 & 5.26 & $0.24(0.02-2.58)$ & 0.24 \\
\hline End-to-End & 3 & 13 & 18.75 & & \\
\hline
\end{tabular}

We can see from Table 1 that in the group who underwent overlapping repair, the sample who had persistent sonographic anal sphincter defect had internal and external anal sphincter defect. Out of the three samples who had failed repair, one sample had internal and external anal sphincter defect, and the other two patients only suffered external anal sphincter defect. However, this difference was not found to be significant statistically.
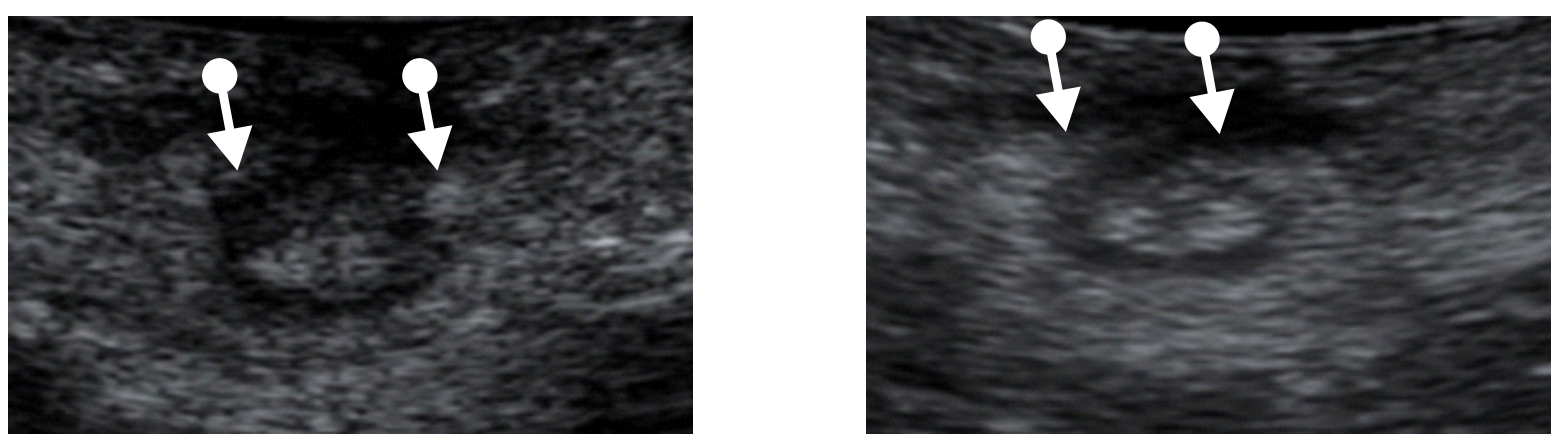

Figure 1. Ultrasonography Pictures for Sample Number 29
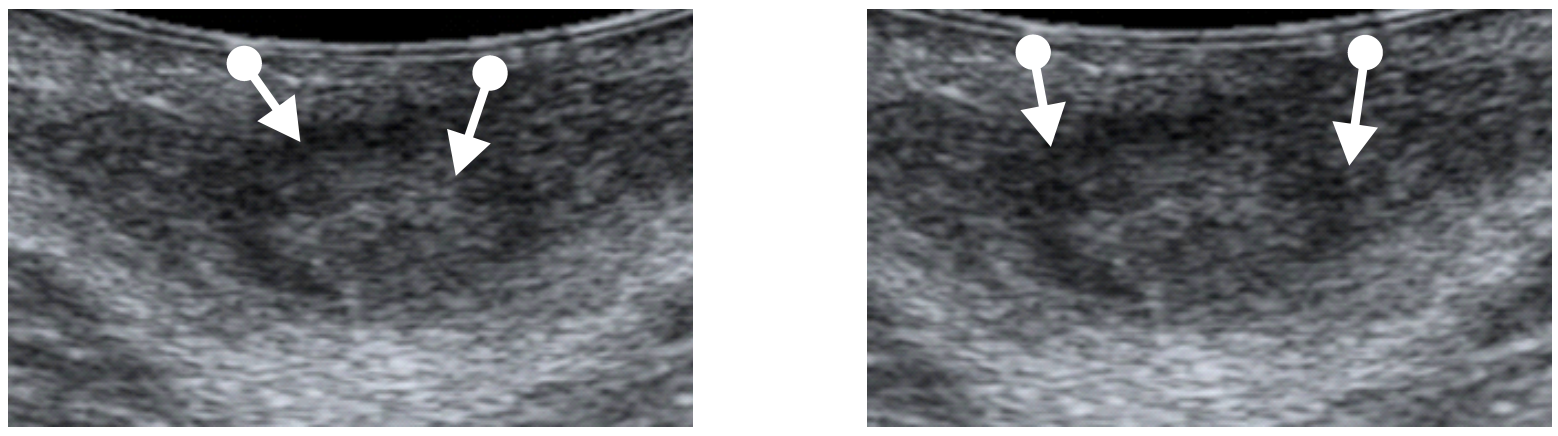

Figure 2. Ultrasonography Pictures for Sample Number 44

Table 2. Success of Perineal Repair (Ultrasonography) at Evaluation Week 6

\begin{tabular}{lccccc}
\hline \hline \multirow{2}{*}{ Repair Technique } & \multicolumn{2}{c}{ Repair Success } & \% & RR (95\%CI) & p \\
\cline { 2 - 3 } & Yes & No & & & \\
\hline Overlapping & 18 & 1 & 94.74 & $4.15(0.39-44.57)$ & 0.31 \\
End-to-End & 13 & 3 & 81.25 & & \\
\hline \hline
\end{tabular}


Table 3. Success of Perineal Repair (Clinical) in Evaluation Weeks 2 and 6

\begin{tabular}{lcccccc}
\hline \hline \multirow{2}{*}{ Repair Technique } & \multicolumn{3}{c}{ Repair Success at Week 2 } & \multicolumn{3}{c}{ Repair Success at Week 6 } \\
\cline { 2 - 7 } & Yes & No & \% & Yes & No & \% \\
\hline Overlapping & 24 & 0 & 100 & 19 & 0 & 100 \\
End-to-End & 24 & 0 & 100 & 10 & 0 & 100 \\
\hline \hline
\end{tabular}

From Table 2 we can see that the success rates of both repair techniques were high, with the overlapping technique having $94.74 \%$ success rate, and the end-to-end technique had $81.25 \%$ success rate. Statistically, no significant difference was found between both groups $(p=0.31)$. However, from Table 3 we can see that no clinical indication of failed repair was found in either groups at both the 2-week and 6-week evaluation.

\section{DISCUSSION}

The research findings show that the samples in both groups are homogeneous. The success of repair was assessed based on the presence or absence of images related to persistent sonographic anal sphincter defect in the $6^{\text {th }}$ week evaluation after repair. In this assessment, successful repair in the overlapping group reached $94.74 \%$, higher than the end-to-end group $(81.25 \%)$. However, it was not found to be significantly different $(p=0.31)$. Some risk factors were jointly present in 3 out of the 4 samples who had failed repairs. However, no variable was found to be more influential than the others in the incidence of persistent sonographic anal sphincter defects.

Clinically and based on the FCSS, evaluation after repair at weeks 2 and 6 indicated successful repair of both groups. There were 3 out of 4 samples with anal sphincter defects, which experienced dehiscence up to the subcutaneous area (one of them even presented with pus), in the evaluation at week 1 after repair. This dehiscence did not reach the external anal sphincter. The treatment given resulted in tissue repair at the $2^{\text {nd }}$ week evaluation.

At the $6^{\text {th }}$ week evaluation after repair, the sample size had been reduced by 13 subjects. This was due to the inability to contact the samples for follow-up until week 12 after the repair. The reason most commonly found for this situation was the return of the samples to their hometown after the completion of their puerperium and the eruption of Mount Merapi in Yogyakarta, especially in the area of Sleman Regency.

Based on the data presented, it remains necessary to conduct further research in Indonesia with more samples in order to generate maximum research findings. The selection of either overlapping or endto-end repair technique should be adapted to the perineal conditions and situations at the time the repair is performed since the success rates of both techniques did not show a significant difference.

\section{CONCLUSION}

In this study, there were no differences in the incidence of persistent sonographic anal sphincter defects after IIIb-IV degree perineal rupture repair using an overlapping technique in comparison with an end-to-end technique. Similarly, there were no differences in terms of repair results in relation to the presence of fecal urgency, anal incontinence, and fecal incontinence.

\section{REFERENCES}

1. Byrd LM, Hobbist J, Tasker M. It is possible to predict or prevent third degree tears? Colorectal Disease 2005; 7: $311-8$

2. Fitzpatrick M. Postpartum care of the perineum. The Obstetrician and Gynaecologist 2007; 9:3:164-70.

3. Power D, Fitzpatrick M, O’Herlihy C. Obstetric anal sphincter injury: How to avoid, how to repair: A literature review. Fam Pract 2006; 55(3): 193-200.

4. Enkin M, Keirse Marc JNC, Neilson J, et al. Repair of perineal trauma. In: A guide to effective care in pregnancy and childbirth. $3^{\text {rd }}$ ed. Oxford: Oxford University Press; 2000.

5. Williams A, Adams EJ, Tincello DG, et al. How to repair an anal sphincter injury after vaginal delivery: result of randomised controlled trial. BJOG 2006; 113(2): 201-7.

6. Thach TS. Methods of repair for obstetric anal sphincter injury: RHL commentary. In: The WHO Reproductive Health Library, 2006.

7. Sultan AH, Thakar R. Third and fourth degree tears. In: Perineal and anal sphincter trauma. London: SpringerVerlag London Limited; 2007: 33-48. 
8. Thakar R, Fenner DE. Anatomy of the perineum and the anal sphincter. In: Perineal and anal sphincter trauma. London: Springer-Verlag London Limited; 2007: 3-12.

9. Leeman L, Spearman M, Rogers R. Repair of obstetric perineal lacerations. Am Fam Phys 2003; 68(8): 1585-90.

10. Rao S, Siddiqui J. Diagnosis of fecal incontinence. In: Ratto C, Doglietto GB, eds. Fecal incontinence: diagnosis and treatment. Milan: Springer Science and Business Media; 2007.

11. Vodusek DB. Anatomy and neurocontrol of the pelvic floor. Digestion 2004; 69: 87-92.

12. Rizvi RM, Chaudhury N. Practices regarding diagnosis and management of third and fourth degree perineal tears. J Pak Med Assoc 2008; 58(5): 244-7.

13. Corton MM. Anatomy of pelvic floor dysfunction. Clin N Am 2009; 36: 401-19.

14. Thomas DC, Carolynne VJ, Michael KA. Obstetric anal sphincter injury: incidence, risk factors, and management. Ann Surg 2008; 247(2): 224-37.

15. Williams A. Third-degree perineal tears: risk factors and outcome after primary repair. J Obstet Gynaecol 2003; 23(6): 611-4.

16. Chigbu B, Onwere S, Aluka C, et al. Factors influencing the use of episiotomy during vaginal delivery in South Eastern Nigeria. E Afr Med J 2008; 85(5): 240-3.

17. Fernando RJ. Anal sphincter injury at childbirth. J Fam Practice 2005.

18. Fernando RJ, Sultan AH, Radley S, et al. Management of obstetric anal sphincter injury: a systematic review and national practice survey. BMC Health Serv Res 2002; 2: 9.

19. Methods and materials used in perineal repair. Royal College of Obstetricians and Gynaecologists, RCOG 2007; 9: 164-70.

20. Sultan AH, Kettle C. Diagnosis of perineal trauma. In: Perineal and anal sphincter trauma. London: SpringerVerlag London Limited; 2007: 13-8.

21. Demirbas S, Atay V, Sucullu I, et al. Overlapping repair in patients with anal sphincter injury. Med Princ Pract 2008; 17: 56-60.
22. Cawich SO, Mitcheli DIG, Martin A, et al. Management of obstetric anal sphincter injuries at the University Hospital of the West Indies. West Ind Med J 2008; 57(5): 482-5.

23. Wagih M. Obstetric regional anesthesia. ASJOG 2005; 3: 8-13.

24. Nicholl M. Management of third and fourth degree perineal tears (Obstetric anal sphincter injury). 2004. Available from: URL:http://www.nsw.gov.au.

25. Bartram C, Sultan AH. Imaging of the anal sphincter. In: Perineal and anal sphincter trauma. London: SpringerVerlag London Limited; 2007: 123-31.

26. Valsky DV, Messing B, Petkova R, et al. Postpartum evaluation of the anal sphincter by transperineal three-dimensional ultrasound in primiparous women after vaginal delivery and following surgical repair of third-degree tears by the overlapping technique. Ultrasound Obst Gyn 2007; 29: 195-204.

27. Thakar R, Sultan AH. Postpartum problems and the role of a perineal clinic. In: perineal and anal sphincter trauma. London: Springer-Verlag London Limited; 2007: 65-76.

28. Wikipedia. Pudendal nerve. 2009. Available from: URL: http://en.wikipedia.org/wiki/Pudendal_nerve.

29. De Bernis L. Pudendal block. In: Managing complications in pregnancy and childbirth: a guide for midwives and doctors. Geneva: Department of Reproductive Health and Research, Family and Community Health, World Health Organization; 2003: 3-6.

30. The Brookside Associates Medical Education Division. Pudendal Block. Mil Obstet Gynecol; 2009.

31. De Bernis L. Local Anaesthesia. In: Managing complications in pregnancy and childbirth: a guide for midwives and doctors. Geneva: Department of Reproductive Health and Research, Family and Community Health, World Health Organization; 2003: C38-45.

32. Nordqvist C. What is bowel incontinence? What is fecal incontinence? What causes bowel incontinence? [Online]. 2009. Available from: URL:http://www.medicalnewstoday.com. 